\title{
The effect of feeding regular or low $\alpha$-linolenic acid linseed on the fatty acid composition of egg yolks
}

\author{
E. Sosin ${ }^{1,4}$, F. Borowiec ${ }^{2}$, J. Strzetelski ${ }^{1}$ and S. Smulikowska ${ }^{3}$ \\ ${ }^{1}$ National Research Institute of Animal Production, \\ Department of Animal Nutrition and Feed Science \\ 32-083 Balice, Poland \\ ${ }^{2}$ Agricultural University of Cracow, Department of Animal Nutrition \\ Al. Mickiewicza 24/28, Kraków, Poland \\ ${ }^{3}$ The Kielanowski Institute of Animal Physiology and Nutrition, Polish Academy of Sciences \\ 05-110 Jablonna, Poland
}

(Received 10 May 2006; revised version 10 August 2006, accepted 6 November 2006)

\begin{abstract}
Ninety Isa Brown laying hens aged 28 weeks, kept in individual cages, were randomly divided into 6 groups of 15 birds each. Six isoproteinous diets differing in crude fat content and fatty acid (FA) composition were prepared. The source of added fat was linseeds (50 g/kg diet), regular cultivars (Omega and Opal) with a high content of $\alpha$-linolenic acid (HA), or a modified cultivar (Linola) with low $\alpha$-linolenic acid- and high linoleic acid (LA) contents, soyabean oil, or LA linseed oil (20 g/ kg diet). The control diet, with no fat supplement, contained $19 \mathrm{~g}$, while the experimental diets, $38 \mathrm{~g}$ of crude fat per $\mathrm{kg}$. The diets were fed for a 12-week and eggs were collected for chemical analysis at weekly intervals. The dietary fat level had no effect on the fat level in egg yolks. Eggs from hens fed diets with HA linseeds contained 3 times more $\alpha$-linolenic acid, 2.5 times more EPA $\left(\mathrm{C}_{20: 5 \mathrm{n}-3}\right)$ and DHA $\left(\mathrm{C}_{22: 6 \mathrm{n}-3}\right)$ and $27 \%$ less arachidonic acid $\left(\mathrm{C}_{20: 4 \mathrm{n}-6}\right)$ than control eggs $(\mathrm{P}<0.01)$. Those from hens fed with LA linseed, LA oil or soyabean oil, had similar levels of linoleic acid, EPA and DHA as control eggs and 14\% more arachidonic acid. The ratio of n-6/n-3 PUFA was 3:1 in eggs from hens provided with HA linseed, while in the other groups it ranged from 9:1 to 14:1. In contrast to regular linseed, the use of linseed low in $\alpha$-linolenic acid and rich in linoleic acid in hen diets is not beneficial for the functional value of eggs.
\end{abstract}

KEY WORDS: regular linseed, modified linseed, egg yolk, fatty acids, PUFA, DHA

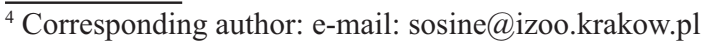




\section{INTRODUCTION}

Consumers are increasingly interested in functional foods, among others in products containing omega-3 (n-3) long-chain polyunsaturated fatty acids (PUFA). Dietary intake of n-3 PUFA has a positive effect on foetal brain development and decreases the risk of several diseases such as coronary artery disease, inflammatory and autoimmune diseases (Krauss et al., 2001; ISSFAL, 2004). The proper supply of eicosapentaenoic acid $\left(\mathrm{C}_{20: 5 n-3,3}, \mathrm{EPA}\right)$ and docosahexaenoic acid $\left(\mathrm{C}_{22: 6 n-3,}\right.$, DHA $)$ is important for newborns and the elderly or people at high risk of diseases, while the dietary supply of their precursor, $\alpha$-linolenic acid $\left(\mathrm{C}_{18: 3 n-3}\right)$, may have beneficial effects on blood lipoprotein characteristics in healthy individuals (Lewis et al., 2000). Linoleic acid $\left(\mathrm{C}_{18: 2 \mathrm{n}-6}\right)$ and other PUFA of the $\mathrm{n}-6$ family are also essential, as both n- 6 and n-3 PUFAs are components of nerve cells and cellular membranes, and they are converted in the body to eicosanoids, leukotriens, and prostaglandins (ISSFAL, 2004). They must, however, be present in balance for optimum health. In Western diets, the balance is weighed heavily in favour of linoleic acid, which may have adverse effects on highdensity lipoprotein concentrations and on immunosuppresion. The recommended ratio of n-6/n-3 PUFA in a healthy human diet is about 2:1 (ISSFAL, 2004).

Kamińska et al. (2001) showed that basing hen diets on different cereals resulted in PUFA n-6/n-3 ratios in egg yolks ranging from 11:1 to $21: 1$. The fatty acid (FA) composition of egg lipids can be modified to better match human nutritional guidelines by manipulating the fatty acid composition of the diet. Eggs enriched with EPA and DHA can be obtained by providing hens with fish oils, fish meals or marine algae, however, this may be associated with undesirable organoleptic characteristics of eggs, i.e. with a fishy flavour (Herber and Van Elswyk, 1996; Leskanich and Noble, 1997). Eggs enriched in $\alpha$-linolenic acid can be obtained by feeding hens linseed of regular cultivars or regular linseed oil (Jiang et al., 1991; Cherian et al., 1995; Scheideler and Froning, 1996; Lewis et al., 2000). Linseed cultivars containing oil with a modified fatty acid profile that is low in $\alpha$-linolenic acid and less susceptible to oxidation have been introduced in recent years, however (Borowiec et al., 2001; Gambuś et al., 2003).

The aim of the present study was to compare the effects of feeding laying hens with regular linseeds or with seeds or oil from the Linola cultivar, which are low in $\alpha$-linolenic acid, on the fatty acid profile and n-6/n-3 PUFA ratio in yolk lipids.

\section{MATERIAL AND METHODS}

The seeds of 3 linseed cultivars, two regular ones high in $\alpha$-linolenic acid (HA), Omega and Opal, and modified cultivar low in $\alpha$-linolenic acid (LA) Linola, were 
used in the study. LA linseed oil and soyabean oil were used as references. The linseeds were ground and incorporated into laying hen diets at the level of $50 \mathrm{~g} / \mathrm{kg}$, plant oils were incorporated at the level of $20 \mathrm{~g} / \mathrm{kg}$ to provide a similar amount of dietary fat; the control diet was not supplemented with fat (Table 1).

Table 1. Composition and nutritional value of diets, $\mathrm{g} / \mathrm{kg}$

\begin{tabular}{|c|c|c|c|c|c|c|}
\hline \multirow{3}{*}{ Item } & \multicolumn{6}{|c|}{ Dietary treatment } \\
\hline & \multirow[b]{2}{*}{ control } & \multicolumn{3}{|c|}{ linseeds } & \multicolumn{2}{|c|}{ vegetable oils } \\
\hline & & $\begin{array}{c}\mathrm{HA}^{1} \\
\text { Omega }\end{array}$ & $\begin{array}{l}\mathrm{HA}^{1} \\
\text { Opal }\end{array}$ & $\begin{array}{c}\mathrm{LA}^{2} \\
\text { Linola }\end{array}$ & $\begin{array}{c}\mathrm{LA}^{2} \\
\text { linseed }\end{array}$ & soyabean \\
\hline \multicolumn{7}{|l|}{ Component } \\
\hline wheat & 577 & 552 & 552 & 547 & 552 & 552 \\
\hline maize & 100 & 100 & 100 & 100 & 100 & 100 \\
\hline soyabean meal & 160 & 135 & 135 & 140 & 165 & 165 \\
\hline meat-and-bone meal & 40 & 40 & 40 & 40 & 40 & 40 \\
\hline dehydrated lucerne & 20 & 20 & 20 & 20 & 20 & 20 \\
\hline mineral-vitamin premix ${ }^{3}$ & 5 & 5 & 5 & 5 & 5 & 5 \\
\hline dicalcium phosphate & 25 & 25 & 25 & 25 & 25 & 25 \\
\hline $\mathrm{NaCl}$ & 3 & 3 & 3 & 3 & 3 & 3 \\
\hline limestone & 70 & 70 & 70 & 70 & 70 & 70 \\
\hline linseeds & - & 50 & 50 & 50 & - & - \\
\hline vegetable oil & - & - & - & - & 20 & 20 \\
\hline \multicolumn{7}{|c|}{ Chemical composition, $\mathrm{g} / \mathrm{kg} D M$} \\
\hline $\mathrm{ME}, \mathrm{MJ} / \mathrm{kg}$ & 11.00 & 11.40 & 11.38 & 11.43 & 11.46 & 11.50 \\
\hline crude protein & 167 & 169 & 168 & 170 & 168 & 169 \\
\hline crude fat & 18.8 & 38.0 & 39.2 & 37.0 & 37.4 & 39.8 \\
\hline$\alpha$-linolenic acid & 0.55 & 7.70 & 7.22 & 1.14 & 0.95 & 1.38 \\
\hline \multicolumn{7}{|c|}{ 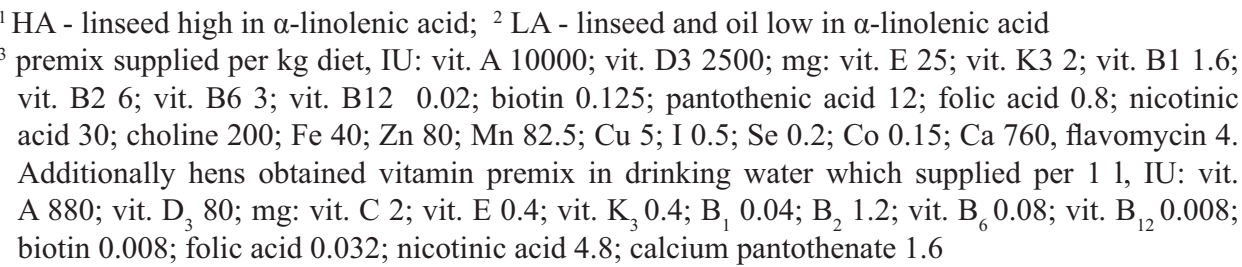 } \\
\hline
\end{tabular}

Ninety Isa Brown laying hens aged 28 weeks were divided into 6 groups of 15 birds and kept in individual cages in a battery system. The environmental conditions in the building were constant, with a temperature of about $22-24^{\circ} \mathrm{C}$, relative moisture of $70 \%$, and a $16 \mathrm{~h}$ light per day. Hens were allotted to 6 dietary treatments. Feed and water were provided ad libitum during the 12-week feeding trial. Eggs were collected and weighed daily at about $6 \mathrm{pm}$. Every week 5 eggs from each group were randomly selected, weighed and cracked. Yolk, albumen 
and eggshell were separated and weighed. Yolks were pooled within a group, homogenized and frozen at $-20^{\circ} \mathrm{C}$ until analysis.

\section{Chemical analysis}

Dry matter and nutrient contents of the experimental diets and yolks were determined according to AOAC (1990). Lipids were extracted from seeds and diets with a mixture of methanol and chloroform at a ratio of $2: 1$. About $2.5 \mathrm{~g}$ of extracted lipids or $1 \mathrm{~g}$ of yolk samples were methylated according to Folch et al. (1957). The fatty acid methyl esters were separated and quantified by an automated Varian 3400 CX gas chromatograph equipped with an on-column injector (set at $200^{\circ} \mathrm{C}$ ), flame ionization detector (set at $250^{\circ} \mathrm{C}$ ), and DB-23 fused capillary column $(30 \mathrm{~m} \times 0.53$ $\mathrm{mm}$ internal diameter). The initial column temperature was set at $100^{\circ} \mathrm{C}$ for $3 \mathrm{~min}$, increased to 160 at $20^{\circ} \mathrm{C} / \mathrm{min}$ and held for $10 \mathrm{~min}$. Then the column temperature was elevated to $205^{\circ} \mathrm{C}$ at a rate of $5^{\circ} \mathrm{C} / \mathrm{min}$ and held at the final temperature for $5 \mathrm{~min}$. Argon was used as the carrier gas. The analyses were performed in duplicate.

\section{Statistical analysis}

The results were subjected to one-way ANOVA GLM analysis (SAS, 1989). The means were compared using Duncan's multi-range test at $\mathrm{P}<0.05$ and $\mathrm{P}<0.01$ level of significance.

\section{RESULTS}

Linseeds of the regular HA cultivars, Omega and Opal, had a high content of $\alpha$-linolenic acid, while linoleic acid predominated in the fatty acids of LA linseed cv. Linola, LA linseed oil, and soyabean oil (Table 2). The control diet contained $19 \mathrm{~g}$ crude fat $/ \mathrm{kg}$, while in the experimental diets the crude fat level was doubled due to the added full-fat seeds or vegetable oils (Table 1). Soyabean oil did not markedly change the dietary FA profile in comparison with the control diet, while the HA seeds increased the proportion of $\alpha$-linolenic acid, the LA seeds and LA oil considerably increased the proportion of linoleic acid in the dietary lipids (Table $3)$. Due to this, the n-6/n-3 PUFA ratio, which was about 13:1 in the control and soyabean-oil diets, decreased to $1.4: 1$ in the diets with HA linseeds, whereas in the diet with LA linseed, it increased to $17: 1$, and in the diet with LA oil, even to 19:1 (Table 3).

The eggs from hens fed experimental diets containing linseeds or vegetable oils were generally smaller than from control birds $(\mathrm{P}<0.05)$, those from birds provided 
Table 2. Major fatty acids (FA) in linseeds and oils used in experimental diets, $\%$ total FA

\begin{tabular}{|c|c|c|c|c|c|}
\hline \multirow[b]{2}{*}{ Fatty acid } & \multicolumn{3}{|c|}{ Linseeds } & \multicolumn{2}{|c|}{ Vegetable oils } \\
\hline & $\begin{array}{c}\mathrm{HA}^{1} \\
\text { Omega }\end{array}$ & $\begin{array}{l}\mathrm{HA}^{1} \\
\text { Opal }\end{array}$ & $\begin{array}{c}\mathrm{LA}^{2} \\
\text { Linola }\end{array}$ & $\begin{array}{c}\mathrm{LA}^{2} \\
\text { linseed }\end{array}$ & soyabean \\
\hline $\mathrm{C}_{14: 0}$ & - & 0.04 & - & 0.05 & 0.05 \\
\hline $\mathrm{C}_{16: 0}$ & 5.82 & 6.32 & 7.6 & 6.17 & 8.2 \\
\hline $\mathrm{C}_{18: 0}$ & 3.85 & 3.25 & 3.15 & 3.23 & 3.05 \\
\hline $\mathrm{C}_{18: 1}$ & 30.0 & 22.5 & 14.1 & 14.2 & 34.9 \\
\hline$C_{18: 2 n-6}$ & 16.4 & 16.0 & 72.8 & 74.1 & 45.8 \\
\hline$C_{18: 3 n-3}$ & 43.9 & 51.5 & 1.8 & 1.91 & 6.8 \\
\hline $\mathrm{C}_{20: 0}$ & - & 0.11 & 0.15 & 0.09 & 0.3 \\
\hline $\mathrm{C}_{20: 1}$ & - & 0.20 & 0.23 & - & 0.32 \\
\hline Other FA & 0.03 & 0.08 & 0.17 & 0.25 & 0.58 \\
\hline SFA & 9.67 & 9.7 & 10.9 & 9.5 & 11.6 \\
\hline MUFA & 30.0 & 22.7 & 14.3 & 14.2 & 35.2 \\
\hline PUFA & 60.3 & 67.5 & 74.6 & 76.0 & 52.6 \\
\hline PUFA n-6/n-3 & 0.37 & 0.31 & 40.0 & 38.8 & 6.74 \\
\hline
\end{tabular}

${ }^{1} \mathrm{HA}$ - linseed high in $\alpha$-linolenic acid; ${ }^{2}$ LA - linseed and oil low in $\alpha$-linolenic acid; SFA - saturated fatty acids; MUFA - monounsaturated fatty acids; PUFA - polyunsaturated fatty acids

Table 3. Major fatty acids in experimental diets, $\%$ total FA

\begin{tabular}{|c|c|c|c|c|c|c|}
\hline \multirow{3}{*}{ Fatty acid } & \multicolumn{6}{|c|}{ Dietary treatment } \\
\hline & \multirow[b]{2}{*}{ control } & \multicolumn{3}{|c|}{ linseeds } & \multicolumn{2}{|c|}{ vegetable oils } \\
\hline & & $\begin{array}{c}\mathrm{HA}^{1} \\
\text { Omega }\end{array}$ & $\begin{array}{l}\text { HA }^{1} \\
\text { Opal }\end{array}$ & $\begin{array}{c}\mathrm{LA}^{2} \\
\text { Linola }\end{array}$ & $\begin{array}{c}\mathrm{LA}^{2} \\
\text { linseed }\end{array}$ & soyabean \\
\hline $\mathrm{C}_{14: 0}$ & 0.43 & 0.19 & 0.29 & 0.22 & 0.32 & 0.21 \\
\hline $\mathrm{C}_{16: 0}$ & 17.5 & 12.4 & 14.1 & 13.2 & 13.9 & 15.5 \\
\hline $\mathrm{C}_{16: 1}$ & 0.93 & 0.41 & 0.14 & 0.35 & 0.17 & 0.22 \\
\hline $\mathrm{C}_{18: 0}$ & 6.02 & 5.31 & 7.72 & 4.80 & 5.75 & 5.29 \\
\hline $\mathrm{C}_{18: 1}$ & 29.0 & 28.1 & 29.5 & 22.92 & 24.2 & 26.8 \\
\hline$C_{18: 2 n-6}$ & 40.5 & 30.7 & 27.6 & 54.18 & 51.8 & 46.7 \\
\hline $\mathrm{C}_{18: 3 \mathrm{n}-3}$ & 3.08 & 21.3 & 19.4 & 3.25 & 2.68 & 3.65 \\
\hline $\mathrm{C}_{20: 0}$ & 0.42 & 0.16 & 0.26 & 0.22 & 0.16 & 0.11 \\
\hline $\mathrm{C}_{20: 1}$ & 1.00 & 0.52 & 0.53 & 0.42 & 0.43 & 0.46 \\
\hline Other FA & 1.15 & 0.85 & 0.50 & 0.41 & 0.63 & 0.97 \\
\hline SFA & 24.4 & 18.1 & 22.3 & 18.47 & 20.1 & 21.1 \\
\hline MUFA & 30.9 & 29.0 & 30.2 & 23.7 & 24.8 & 27.5 \\
\hline PUFA & 43.5 & 52.0 & 47.0 & 57.43 & 54.5 & 50.4 \\
\hline PUFAn-6/n-3 & 13.2 & 1.4 & 1.4 & 16.6 & 19.3 & 12.8 \\
\hline
\end{tabular}

${ }^{1} \mathrm{HA}$ - linseed high in $\alpha$-linolenic acid; ${ }^{2}$ LA - linseed and oil low in $\alpha$-linolenic acid; SFA saturated fatty acids; MUFA - monounsaturated fatty acids; PUFA - polyunsaturated fatty acids 
the LA oil diet were 4\% smaller than control eggs. Yolk weight as well as dry matter, crude protein and fat content in yolks were uniform among groups (Table 4).

The egg yolk fatty acid profiles from hens fed the experimental diets are presented in Table 5. Oleic acid $\left(\mathrm{C}_{18: 1}\right)$ was the major fatty acid in all groups, followed by palmitic $\left(\mathrm{C}_{16: 0}\right)$ and linoleic acids. Apart from palmitic acid, which was relatively constant in all groups $(24.5 \% \mathrm{FA}$, on average), the remaining fatty

Table 4. Egg weight and chemical composition of yolks, $\%$

\begin{tabular}{|c|c|c|c|c|c|c|c|}
\hline \multirow{3}{*}{ Item } & \multicolumn{7}{|c|}{ Dietary treatment } \\
\hline & \multirow[b]{2}{*}{ control } & \multicolumn{3}{|c|}{ linseeds } & \multicolumn{2}{|c|}{ vegetable oils } & \multirow[b]{2}{*}{ SEM } \\
\hline & & $\begin{array}{c}\mathrm{HA}^{1} \\
\text { Omega }\end{array}$ & $\begin{array}{l}\mathrm{HA}^{1} \\
\text { Opal }\end{array}$ & $\begin{array}{c}\mathrm{LA}^{2} \\
\text { Linola }\end{array}$ & $\begin{array}{c}\mathrm{LA}^{2} \\
\text { linseed }\end{array}$ & soyabean & \\
\hline Egg weight, $g$ & $61.2^{\mathrm{b}}$ & $60.6^{\mathrm{a}}$ & $59.9^{\mathrm{a}}$ & $59.5^{\mathrm{a}}$ & $58.7^{\mathrm{a}}$ & $60.8^{\mathrm{a}}$ & 0.31 \\
\hline Yolk weight, g & 15.3 & 15.5 & 15.2 & 15.1 & 15.3 & 15.3 & 0.12 \\
\hline Yolk, g/100g whole egg & $25.0^{\mathrm{a}}$ & $24.7^{\mathrm{a}}$ & $25.3^{\mathrm{a}}$ & $25.4^{\mathrm{a}}$ & $26.1^{\mathrm{b}}$ & $25.2^{\mathrm{a}}$ & 0.14 \\
\hline Dry matter in yolk, \% & 49.4 & 49.8 & 50.0 & 49.5 & 49.4 & 49.2 & 0.10 \\
\hline Crude protein in yolk, $\%$ & 16.5 & 16.5 & 16.5 & 16.6 & 16.4 & 16.4 & 0.04 \\
\hline Crude fat in yolk, $\%$ & 27.5 & 27.7 & 27.7 & 27.2 & 27.3 & 27.2 & 0.07 \\
\hline
\end{tabular}

a,b means in row with no common superscripts are significantly different at $\mathrm{P}<0.05$

${ }^{1} \mathrm{HA}$ - linseed high in $\alpha$-linolenic acid; ${ }^{2} \mathrm{LA}$ - linseed and oil low in $\alpha$-linolenic acid

Table 5. Major fatty acids in yolk lipids, $\%$ of total FA

\begin{tabular}{|c|c|c|c|c|c|c|c|}
\hline \multirow{3}{*}{ Fatty acid } & \multicolumn{7}{|c|}{ Dietary treatment } \\
\hline & \multirow[b]{2}{*}{ control } & \multicolumn{3}{|c|}{ linseeds } & \multicolumn{2}{|c|}{ vegetable oils } & \multirow[b]{2}{*}{ SEM } \\
\hline & & $\begin{array}{c}\mathrm{HA}^{1} \\
\text { Omega }\end{array}$ & $\begin{array}{l}\text { HA }^{1} \\
\text { Opal }\end{array}$ & $\begin{array}{c}\mathrm{LA}^{2} \\
\text { Linola }\end{array}$ & $\begin{array}{c}\mathrm{LA}^{2} \\
\text { linseed }\end{array}$ & soyabean & \\
\hline $\mathrm{C}_{14: 0}$ & $0.43^{\mathrm{a}}$ & $0.35^{\mathrm{b}}$ & $0.33^{\mathrm{b}}$ & $0.33^{\mathrm{b}}$ & $0.37^{\mathrm{ab}}$ & $0.40^{\mathrm{ab}}$ & 0.01 \\
\hline $\mathrm{C}_{16: 0}$ & 25.1 & 24.2 & 24.37 & 24.6 & 24.78 & 24.25 & 0.10 \\
\hline $\mathrm{C}_{16: 1}$ & $4.13^{\mathrm{A}}$ & $3.57^{\mathrm{AB}}$ & $3.63^{\mathrm{AB}}$ & $2.87^{\mathrm{B}}$ & $3.13^{\mathrm{B}}$ & $3.09^{\mathrm{B}}$ & 0.01 \\
\hline $\mathrm{C}_{18: 0}$ & $8.82^{\mathrm{B}}$ & $9.23^{\mathrm{AB}}$ & $8.80^{\mathrm{B}}$ & $10.27^{\mathrm{A}}$ & $9.63^{\mathrm{AB}}$ & $9.67^{\mathrm{AB}}$ & 0.12 \\
\hline $\mathrm{C}_{18: 1}$ & $45.6^{\mathrm{A}}$ & $44.3^{\mathrm{A}}$ & $45.36^{\mathrm{A}}$ & $41.37^{\mathrm{B}}$ & $40.71^{\mathrm{B}}$ & $41.3^{\mathrm{B}}$ & 0.28 \\
\hline$C_{18: 2 n-6}$ & $11.3^{\mathrm{B}}$ & $11.9^{\mathrm{B}}$ & $11.65^{\mathrm{B}}$ & $15.70^{\mathrm{A}}$ & $16.94^{\mathrm{A}}$ & $16.1^{\mathrm{A}}$ & 0.30 \\
\hline $\mathrm{C}_{18: 3 \mathrm{n}-3}^{1.20}$ & $0.92^{\mathrm{B}}$ & $2.70^{\mathrm{A}}$ & $2.33^{\mathrm{A}}$ & $1.13^{\mathrm{B}}$ & $0.82^{\mathrm{B}}$ & $1.26^{\mathrm{B}}$ & 0.11 \\
\hline $\mathrm{C}_{20: 1}$ & $0.36^{\mathrm{B}}$ & $0.30^{\mathrm{B}}$ & $0.28^{\mathrm{B}}$ & $0.31^{\mathrm{B}}$ & $0.29^{\mathrm{B}}$ & $0.40^{\mathrm{A}}$ & 0.01 \\
\hline$C_{20: 4 n-6}$ & $1.55^{\mathrm{A}}$ & $1.15^{\mathrm{B}}$ & $1.13^{\mathrm{B}}$ & $1.79^{\mathrm{A}}$ & $1.79^{\mathrm{A}}$ & $1.73^{\mathrm{A}}$ & 0.005 \\
\hline $\mathrm{C}_{20: 5 \mathrm{n}-3}(\mathrm{EPA})$ & traces & 0.25 & 0.2 & traces & traces & traces & \\
\hline $\mathrm{C}_{22: 6 \mathrm{n}-3}(\mathrm{DHA})$ & $0.54^{\mathrm{B}}$ & $1.39^{\mathrm{A}}$ & $1.29^{\mathrm{A}}$ & $0.50^{\mathrm{B}}$ & $0.53^{\mathrm{B}}$ & $0.59^{\mathrm{B}}$ & 0.005 \\
\hline SFA & $34.4^{\mathrm{AB}}$ & $33.8^{\mathrm{B}}$ & $33.5^{\mathrm{B}}$ & $35.2^{\mathrm{A}}$ & $34.8^{\mathrm{AB}}$ & $34.3^{\mathrm{AB}}$ & 0.14 \\
\hline MUFA & $50.1^{\mathrm{A}}$ & $48.2^{\mathrm{B}}$ & $49.3^{\mathrm{B}}$ & $44.6^{\mathrm{C}}$ & $44.1^{\mathrm{C}}$ & $44.8^{\mathrm{C}}$ & 0.33 \\
\hline PUFA n-3 & $1.45^{\mathrm{A}}$ & $4.34^{\mathrm{B}}$ & $3.82^{\mathrm{B}}$ & $1.63^{\mathrm{A}}$ & $1.35^{\mathrm{A}}$ & $1.85^{\mathrm{A}}$ & 0.14 \\
\hline PUFA n-6 & $12.9^{\mathrm{B}}$ & $13.1^{\mathrm{B}}$ & $12.8^{\mathrm{B}}$ & $17.49^{\mathrm{A}}$ & $18.73^{\mathrm{A}}$ & $17.79^{\mathrm{A}}$ & 0.33 \\
\hline PUFA n-6/n-3 & $9.0^{\mathrm{B}}$ & $3.0^{\mathrm{C}}$ & $3.35^{\mathrm{C}}$ & $10.7^{\mathrm{B}}$ & $13.9^{\mathrm{A}}$ & $9.6^{\mathrm{B}}$ & 0.60 \\
\hline
\end{tabular}

${ }_{\mathrm{a}, \mathrm{b}}$ means in a row with no common superscripts are significantly different at: ${ }^{\mathrm{a}, \mathrm{b}} \mathrm{P}<0.05 ;{ }^{\mathrm{A}, \mathrm{B}} \mathrm{P}<0.01$

${ }^{1} \mathrm{HA}$ linseed high in $\alpha$-linolenic acid ${ }^{2}$ LA linseed and oil low in $\alpha$-linolenic acid; SFA - saturated fatty acids; MUFA - monounsaturated fatty acids; PUFA - polyunsaturated fatty acids 
acids were significantly influenced by the dietary FA profile. In yolks from hens fed both HA linseed cultivars, saturated fatty acid levels were lower than in the group provided with LA linseed $(\mathrm{P}<0.01)$. In yolks from hens fed with LA linseed, LA linseed oil, and soyabean oil, the levels of palmitoleic $\left(\mathrm{C}_{16: 1}\right)$ and oleic acids were lower than in the control group. Yolks from hens fed diets with HA linseeds contained 3 times more $\alpha$-linolenic acid, 2.5 times more DHA $\left(\mathrm{C}_{22: 6 n-3}\right)$, more EPA $\left(\mathrm{C}_{20: 5 \mathrm{n}-3}\right)$, and $37 \%$ less arachidonic acid $\left(\mathrm{C}_{20: 4 \mathrm{n}-6}\right)$, than control eggs $(\mathrm{P}<0.01)$, while in eggs from hens fed with LA linseed, LA linseed oil or soyabean oil the levels of these acids were similar as in control eggs. Generally, yolks from hens fed diets with HA linseeds contained more n-3 PUFA, yolks from hens fed with LA linseed, LA linseed oil or soyabean oil had similar proportions of n-3 PUFA but more linoleic acid than yolks from control hens $(\mathrm{P}<0.01)$. Due to this, the $n-6 / n-3$ PUFA ratio was about 3:1 in yolks from hens fed with HA linseeds, 9:1 in yolks from hens fed with control and soyabean-oil diets, while in yolks from hens fed with LA linseed it came to 11:1, whereas with LA linseed oil, 14:1.

\section{DISCUSSION}

The fatty acid compositions of HA (Omega and Opal cvs.) and LA (Linola cv.) linseeds were similar to those shown by Borowiec et al. (2001) and Gambuś et al. (2003). The Linola cultivar has been modified in an attempt to increase the oxidative stability of oil. Its oil is low in $\alpha$-linolenic acid and rich in linoleic acid. Whereas in regular linseed cultivars the n-6/n-3 PUFA ratio is about 0.3-0.5:1 (Jiang et al., 1991; Borowiec et al., 2001; Nguyen et al., 2003), in modified LA linseed cultivars, it averages 36-40:1 (Borowiec et al., 2001; Gambuś et al., 2003).

The effect of the linseeds or oils used in this study on laying performance was reported previously (Augustyn et al., 2006). The laying rate in the group fed the diet with LA linseed oil was comparable to the control (90.8 vs $91.4 \%$, respectively), while in the remaining groups it was $95 \%$, on average $(\mathrm{P}<0.05)$. The eggs from hens fed experimental diets were generally smaller than from control birds, similarly as reported by Scheideler and Froning (1996) using a diet with $5 \%$ ground linseed. In the present study total egg weights in the control and experimental groups were very uniform, and averaged $4.73 \mathrm{~kg}$ per hen during 12 weeks of laying. Dietary fat content and composition had no influence on yolk weight or its protein and fat content, which is in agreement with the results of Cherian et al. (1995).

In the present study the levels of MUFA and SFA in yolk FA were speciesspecific: oleic acid predominated, followed by palmitic acid, similarly as described 
by Leskanich and Noble (1997). It seems that the ability of hens to increase oleic acid in the yolk is limited. Jiang et al. (1991) found only a 17\% increase in oleic acid in yolk total lipids in the experimental group, even though the oleic acid content in the experimental diet was twice that of the control diet. On the other hand, PUFA levels and the n-6/n-3 PUFA ratio are more easily altered by dietary FA. In the present study, less total PUFA was deposited in eggs from the control birds due to the lower dietary fat supply. It is interesting that the levels of $\alpha$-linolenic acid and DHA in yolk lipids were similar in eggs from hens fed with LA linseed, LA linseed oil, soyabean oil and in eggs of the control hens, despite the control diet supplying half of the amount of $\alpha$-linolenic acid as the experimental ones. Birds cannot synthesize fatty acids of the n-3 series (Brenner, 1981). Nonetheless, when the dietary supply is very low, dietary n-3 PUFA are very efficiently retained, as was found by Nguyen et al. (2003) in broiler chickens.

In the present study, EPA was present in measurable amounts $(0.2$ or $0.25 \%$ FA) only in yolks from hens fed regular linseeds. DHA constituted $0.54 \%$ of yolk FA in the control group, and from 0.5 to $0.59 \%$ in groups fed with LA linseed, LA oil, or soyabean oil. Scheideler and Froning (1996) found 0.52\% DHA in yolk FA in hens provided with a control diet, Jiang et al. (1991), 0.5\% DHA in yolk FA in hens fed a diet with a low level of $\alpha$-linolenic acid. This indicates that the proper level of DHA is vital for the developing embryo and available dietary sources of the precursor, $\alpha$-linolenic acid, are very effectively utilized for DHA synthesis.

The $n-6 / n-3$ PUFA ratio is the most important factor determining the functional value of eggs. The recommended ratio of n-6/n-3 PUFA in a healthy human diet is about 2:1 (ISSFAL, 2004). Kamińska et al. (2001) reported that hens fed diets with n-6/n-3 PUFA ratio from 13:1 (wheat-based) to 38:1 (maize-based) laid eggs with n-6/n-3 PUFA ratios from 11:1 to 21:1. In the present study, the n-6/n-3PUFA ratio neared 3:1 in eggs from hens fed HA linseeds, fulfilling the recommendation for functional food, while in the groups fed LA linseed or LA linseed oil it was even higher than in eggs from hens fed the control diet. The proper balance between long-chain n-6 PUFA, mainly arachidonic acid, which is used for the synthesis of pro-inflammatory prostaglandins, and long-chain n-3 PUFA (EPA and DHA), exerting anti-inflammatory effects, is also very important for the functional characteristics of eggs (Jiang and Sim, 1993). In the present study, feeding LA linseed and LA oil increased the arachidonic acid level by 15\%, while that of EPA and DHA was similar in comparison with the control eggs. Feeding HA linseed increased the EPA and DHA level 2.5-fold and reduced the arachidonic acid level in yolks by $27 \%$ in comparison with the control eggs. Similarly, Herber and Van Elswyk (1996), and Gao and Charter (2000) reported that an increase in the dietary level of n-3 PUFA resulted in a decrease in the content of n-6 PUFA in yolk, while Boudreau et al. (1991) showed that a decrease in the dietary n-6/n-3 PUFA ratio 
is more effective in limiting n-6 PUFA elongation than an increase in the total amount of n-3 fatty acids consumed. It has been recognized that the enzymatic pathways for the synthesis of long-chain metabolites of n- 6 and n-3 fatty acids are shared; both use $\Delta 6$ desaturase and compete for it (Brenner, 1981).

\section{CONCLUSIONS}

The regular linseed cultivars, Opal and Omega, included into laying hen diets can bring about beneficial changes in the fatty acid profile of egg yolk, decreasing the n-6/n-3 PUFA ratio and arachidonic acid level and increasing EPA and DHA levels. Such eggs can be called enriched eggs or functional food. The use of linseed with a FA composition modified to contain a low level of $\alpha$ linolenic acid and rich in linoleic acid can not be associated with health benefits for egg consumers.

\section{REFERENCES}

AOAC, 1990. Official Methods of Analysis, Association of Official Analytical Chemists. $15^{\text {th }}$ Edition. Washington, DC

Augustyn R., Barteczko J., Smulikowska S., 2006. The effect of feeding regular or low $\alpha$-linolenic acid linseed on laying performance and total cholesterol content in eggs. J. Anim. Feed Sci. 15, Suppl. 1, 103-106

Borowiec F., Zając T., Kowalski Z.M., Micek P., Marciński M., 2001. Comparison of nutritive value of new commercial linseed oily cultivars for ruminants. J. Anim. Feed Sci. 10, 301-308

Boudreau M., Chanmguam P., Hart S., Lee S.H., Hwang D.H., 1991. Lack of dose response by dietary n-3 fatty acids at a constant n-3:n-6 fatty acid ratio in suppressing eicosanoid biosynthesis from arachidonic acid. Amer. J. Clin. Nutr. 54, 111-117

Brenner R.R., 1981. Nutritional and hormonal factors influencing desaturation of essential fatty acids. Prog. Lipid Res. 20, 41-47

Cherian G., Li G.S.X., Sim J.J., 1995. Dietary $\alpha$-linolenic acid and laying hen strain: fatty acids of liver, adipose tissue, white meat, dark meat and egg yolk. J. Agr. Food Chem. 43, 2554-2559

Folch J., Lees M., Sloane-Stanley G.H., 1957. A simple method for the isolation and purification of total lipids from animal tissues. J. Biol. Chem. 226, 497-509

Gambuś H., Borowiec F., Zając T., 2003. Chemical composition of linseed with different colour of bran layer. Pol. J. Food Nutr. Sci. 3, 67-70

Gao Y.C., Charter E.A., 2000. Nutritionally important fatty acids in hen egg yolks from different sources. Poultry Sci. 79, 921-924

Herber S.M., Van Elswyk M.E., 1996. Dietary marine algae promote efficient deposition of n-3 fatty acids for the production of enriched shell eggs. Poultry Sci. 75, 1501-1507

ISSFAL, 2004. The $6^{\text {th }}$ Congress of the International Society for the Study of Fatty Acids and Lipids, Brighton (UK)

Jiang Z., Ahn D.U., Sim J.S., 1991.Effects of feeding flax and two types of sunflower seeds on fatty acid composition of yolk lipid classes. Poultry Sci. 70, 2467-2475 
Jiang Z., Sim J.S., 1993. Consumption of n-3 polyunsaturated fatty acid enriched eggs and changes in plasma lipids of human subject. Nutrition 9, 513-518

Kamińska B., Gąsior R., Skraba B., 2001. Modification of polyunsaturated fatty acid contents in yolk lipids using various cereals and blended animal fat in hens diets. J. Anim. Feed Sci. 10, Suppl. 2, 255-260

Krauss R.M., Eckel R.H., Howard B., Appel L.J., Daniels S.R., Deckelbaum R.J., Erdman J.W., KrisEtherton P., Goldberg I.J., Kotchen T.A., Lichtenstein A.H., Mitch W.E., Mullis R., Robinson K., Wylie-Rosett J., Jeor S.S., Suttie J., Tribble D.L., Bazzarre T.L., 2001. Revision 2000: A statement for healthcare professionals from the Nutrition Committee of the American Heart Association. J. Nutr. 131, 132-146

Leskanich C.O., Noble R.C., 1997. Manipulation of the n-3 polyunsaturated fatty acid composition of avian eggs and meat. World Poultry Sci. J. 53, 155-183

Lewis N.M., Seburg S., Flanagan N.L., 2000. Enriched eggs as a source of n-3 polyunsaturated fatty acids for humans. Poultry Sci. 79, 971-974

Nguyen C.V., Smulikowska S., Mieczkowska A., 2003. Effect of linseed and rapeseed or linseed and rapeseed oil on performance, slaughter yield and fatty acid deposition in edible parts of the carcass in broiler chickens. J. Anim. Feed Sci. 12, 271-288

SAS, 1989. User Guide, Statistics. ver. 6, SAS Inst. Inc. Cary, NC

Scheideler S.E., Froning G.W., 1996. The combined influence of dietary flaxseed variety, level, form and storage conditions on egg production and composition among vitamin E supplemented hens. Poultry Sci. 75, 1221-1226 